and always in front of the bodies of the vertebre. (Fig. $\mathrm{X}$.) It should be noted in examining doubtful shadows in the abdomen that disease may alter the relation of the organs. Thus, a movable kidney has a wide excursion, and in the antero-posterior view the shadow thrown by a calculus in such a kidney may be found below the crest of the ilium. Further, mobility of the kidney may completely change the relation of the organ to the vertebral bodies in lateral radiography. If a patient with a movable kidney is turned on the side the organ falls forwards and a stone shadow may be thrown in front of the anterior margin of the bodies of the vertebræ. To avoid this displacement the lateral view must be taken with the patient lying on his back. Lateral prelography with an opaque catheter in the ureter will, in any case, settle the relation of the doubtful shadow to the ureter and renal pelvis.

A stone in a greatly enlarged and adherent kidne $\mathrm{V}$ will throw a shadow in front of the spine. (Fig. XIII.)

TrEaturent,

In 11 of the 42 cases of calcilied abdominal glands I operated and removed the glands. In 10 of these cases the operation was planned for the removal of the glands, and in one a calculus was removed from the kidney and the gland was uncovered in stripping up the ascending colon and removed at the same time. One other case was operated upon, on my advice, by Mr. G. H. Percival, of Torthampton, who removed three calcareous glands. The result of the operation on these cases was the disappearance of the pain, whether it had the form of constant aching or recurrent attacks of colic. In one case, that of a very stout woman with a large caseous gland near the upper end of the mesenteric attachment, there were several attacks of acute pain soon after the operation, but these have now ceased and there has been no further attack. All the other cases have remained free from pain since the operation. In the case of severe, recurrent, painless hematuria that I have described in detail, the attacks of hæmaturia have ceased and the patient has returned to practically normal life after being an invalid for about eight years.

These results have justified the operation. and although the number is not large, it is sufficient, I think, to lift the operation out of the purely experimental or speculative stage. The question as to whether the operation should be recommended in all cases where calcified mesenteric glands are discovered is, however, open to discussion. The evil results of the glands in my cases was practically confined to the causation of pain.

It the end stage of the disease there is no longer any danger of general dissemination of the tubercle bacillus, nor, in my opinion, is there any probability of infection of the urinary tract. Tuberculous peritonitis is not a concomitant or a sequel of this condition, and adhesions which might interfere with the action of the bowel or form obstructing bands do not form. From the point of view of the possible development of these complications, therefore, operation need not be considered.

The question is, I think, largely one of the degree of severity of the svmptoms, and this will frequently be decided by the patient himself. In 16 of the 42 cases operation was suggested, and was either refused or indefinitely postponed by the patient, owing to the operation being considered too severe a method of treatment for the symptoms or to a temporary lull in the symptoms. In children this view is subject to modification. Here there is some probability of other more recently infected glands being present alongside the calcareous glands which throw a shadow.

- Igainst any general rule of operation in these cases in children is, however, the knowledge that recovery without operation must take place in the great majority of these cases without further trouble. The fact that a large number of cases of calcified abdominal glands are now discovered during routine examination in adults itself lends support to this conclusion. C'arson, Corner, and Branson all adrocate operation. in children, the two former authorities from the point of view of local abdominal conditions, and the latter from the fear of general complications. Corner lars it down rery definitely that operation should only be performed in these cases where a palpable swelling in the abdomen is detected. This narrows the field to quite a small minority of cases in children.

IIy view in regard to adults where the calcareous end-stage of tabes mesenterica has been reached, is that operation is ondy justifiable in those cases in which symptoms are serere and are proved to be directly due to the calcified glands. These cases can be selected only after investigation by thorough modern methods of examination. The operation presents no great difficulties, but requires care and patience to remove the calcareous masses by blunt dissection. A paramedian incision to the right or left of the mid-line was used and care taken to aroid injury to the superior mesenteric artery and its branches and to the numerous veins that adhere to the glands.

References.

1. Goodhart, Sir $J$, and Still, $G$, F, : Diseases of Children, 1921

2. Comer, E. MI. : Tre L.Mrcer, 1905, ii., 182.5.

3. Branson, w. 1 ;. S.: Truns. Ros. Ifed, and Chirurg. Soc., 1905, p. 349 .

4. Carson, H. W. : THE LANCET, 1918, i., 869.

5. Fordyce. A. 1).: Brit. Med. Jour., 1909, ii, 762.

F. Boston IIed. and Surg. Jour., 1912. 7. Woodhead, G. sims : Reports of Lab. of IRoy. Coll. Phys. Edin., 1888

9. Colman, W. S. : Brit. Med. Jour., 1893, ii., 740. 903 ii., 129 .

10. Jamiesou, J. K., and Dobson, J. F. : THe L.1NCKT, 1907 i., 1137 .

11. Martin, Sidney: Allbutt's System of Medicine, iii., 660

Urolog: 13. Knox, R. : Areh. Radiology and Electrotherapy, 1919.

\section{SOME INVESTIGATIONS INTO A CASE OF PAROXYSMAL HEMOGLOBINCRIA.}

BF Dr. L. S. H.INNEMA,

CONSULTING PHYSICIN TO THE MLNICIPAL HOSPTTAL, ROTTERDAM ; AND

J. R. RYTMA, ASSISTANT PHYSICILN.

THE following paper contains an account of some investigations concerning a patient, a man aged 47 years, admitted into the hospital at Rotterdam in January, 1921, who had been suffering for two years from paroxysmal hæmoglobinuria.

History.-The patient had noticed that the attacks only occurred after exposure to cold. In the warm season he was never troubled by them. The attacks began with shivering and a feeling of extreme cold in his feet and hands the hands turned white and sometimes became somewhat numbed. He had no headache or pain in the joints. During attacks he often had nausea and occasionally he vomited The attacks were accompanied by feverish symptoms, and came at regular intervals, generally in the morning; by evening the attack would have passed off. The patient had never had ermptions of the skin, nor pruritus : he had become paler and thinner during the few months prior to examination and soon felt tired and exhausted. It is interesting to note that he admitted having had syphilis some years before.

Condition on Examination.-The patient looked wellnourished. The mucous membranes were moderatels coloured. There was a slight icteric discolouration of the sclere. In the neck and axillæ a few small glands could to felt. The pulse was normal as to rate and other qualities. The heart and lungs were normal ; on percussion the liver was perhaps somewhat enlarged, but could not be distinctly felt. The spleen was not enlarged. In the abdomen nothing special wás noticed. There was no dropsy and no abnormality of the nervous system. The urine contained albumin and no sugar; the urobilin reaction was positive. In the urine was a brown gramular sediment, together with some normally coloured and some colourless errthrocytes and a few granulated casts. On the day of admission the A 42 
urine had a brownish-hlack colour. Two days later it had pecovered its normal colour and contained no sediment or albumin. The slight yellow discolonration of the scleræ had also rapidly disappeared. The blood contained 60 per cent. hæmoglobin, $3,700,000$ ery throcytes, and 6100 leucocytes in normal proportions; microscopical examination revealed nothing of importance. The Wassermann reaction was 100 per cent. positive.

During the patient's atay in hospitai (about two months) there was no rise in temperature; he had no attack of hæmoglobinuria and did not feel ill:

\section{Remarks.}

The notes of the case and the few symptoms observed on admission made it very probable that the patient was suffering from paroxysmal hæmoglobinuria. Most investigators attribute a great diagnostic value in this disease to a positive reaction of Donath and Landsteiner, which is carried out as follows:-

Either the patient's defibrinated blood, or his serum, to which a quantity of his washed corpuscles are added, is placed for half an hour in ice, after which it is put into an incubator at $37^{\circ} \mathrm{C}$, , whereupon intensive hæmolysis appears. It is believed that the serum of persons suffering from paroxysmal hæmoglobinuria contains an amboceptor which is fixed to the erythrocytes at low temperatures, but not at $37^{\circ} \mathrm{C}$. ; at the temperature of the incubator the complement can bring about hæmolysis of the sensitiscd erythrocytes. Thus sufferers from paroxysmal hæmoglobinuria, according to Donath and Landsteiner, possess an auto-hæmolysin which only becomes active after the blood has been exposed to refrigeration.

It would lead too far to discuss all that has been written on Donath and Landsteiner's experiment. Suffice it to say that most, but not all, authors obtained positive results. It is quite evident that Donath and Landsteiner's experiment is a very rough imitation of nature. It is true that refrigeration is necessary to bring about an attack of paroxysmal hæmoglobinuria, but such a severe reduction of temperature of the blood in the body as is needed for the experiment as carried out by these workers will never actually take place.

Before discussing the conclusions to which these experiments have led us in the case of our own patient, we shall devote a few words to Donath and Landsteiner's experiment. Hymans van den Bergh and C. Hymans applied this experiment to three patients. In one case they observed the remarkable fact that the blood, coagulated at $37^{\circ} \mathrm{C}$, produced clear serum, in which there was no solution of hæmoglobin, while the blood coagulated at normal indoor temperature showed hæmolysis quite plainly. They believed the explanation to be as follows: Donath and Landsteiner's amboceptor is supposed to combine with the erythrocytes at a minimum temperature of $0^{\circ} \mathrm{C}$, a maximum of $37^{\circ}$, the complement combining best at $37^{\circ}$ and not at $0^{\circ} \mathrm{C}$. This would lead one to suppose that between $0^{\circ} \mathrm{C}$. and $37^{\circ} \mathrm{C}$. there lies a temperature at which both of the components in question would be active. Experiments in coagulating the patient's serum made at various temperatures exhibited the most active form of hæmolysis at $10^{\circ} \mathrm{C}$.; above and below this point hæmolysis was less strongly marked. In two cases (the third patient had meanwhile left the hospital) Hymans van den Bergh and $\mathrm{C}$. Hymans found Donath and Landsteiner's test always positive "with the patient's serum obtained at $37^{\circ} \mathrm{C}$.; if they used serum obtained at ordinary indoor temperature, the reaction was negative. These results were confirmed by Rosin. Our own experiences with Donath and Landsteiner's test in the case of our patient coincide with those of Hymans van den Bergh and his assistant.

Wethod of Experiment.-A vein puncture was made; some of the blood taken was immediately placed in an incubator, some was preserved at ordinary indour temperature, some was caught in a tube, containing sterile phrsiological salt olution, after which the blood corpuscles were freed from the plasma by repeated washing. With the serum taken at $37^{\circ} \mathrm{C}$, , as well as that obtained at ordinary indoor temporature, Donath and I andsteiner's test was applied $(1$ vol. serum $+1 / 5$ vol. ervthrocvtes, $\frac{1}{2}$ hour in ice, then 1 hour at $37^{\circ} \mathrm{C}$; as a control the same mixture was placed for $1 \frac{1}{2}$ hours in the incubator). Now it repeatediy appeared: (1) that the serum taken at $37^{\circ}$ was alwars perfectls clear : (2) that the serum taken at normal indoor temperature shorred som. degree of hæmolysis; (3) that Donath and Landsteiner test with the first serum was always positive; and (1) tha: this test with the second serum was always negative.

As we have remarked above, Donath and Landsteiner's test demands conditions in vitro which in vivo cannot be supposed to exist. The following experiments of Hymans van den Bergh and C. Hymans ar. more satisfactory in this respect. They acted on the hypothesis that in an actual attack of hæmoglobinuria some substance must be present which in the experiments in vitro had been disregarded; this substance they supposed to be carbonic acid. We know how many sufferers from paroxysmal hæmoglobinuria exhibit vaso-motor disturbances, where accumulation of carbonic acid is possible. Moreorer, Chvostek harl noted that in some cases ligature of an extremity alon. was sufficient, without any reduction of temperature. to bring about an attack, and thirdly it is known from Hamburger's experiments that carbonic acid is capabl of diminishing the resistance offered by erythrocytes. This last fact also was responsible for the introduction by Hymans van den Bergh and C. Hymans of carbonic acid into their experiments, although, as we shall presently show, neither their results nor our own permit of our acknowledging any direct influenct of carbonic acid on the erythrocytes in paroxysmal hæmoglobinuria.

Hymans van den Bergh and C. Hymans began their experiments by placing defibrinated blood in watchglasses. One of these was left in the air at normal indoor temperature; a second was placed under a bell-jar filled with carbonic acid gas at normal indoor temperature, a third in an incubator at $37^{\circ} \mathrm{C}$, and a fourth in an incubator filled with carbonic acid gas at $37^{\circ}$ C. Repeated tests made in this way with blood taken from the two patients proved that only the defibrinated blood which had stood at ordinary temperature in the carbonic acid atmosphere showed strong hæmolysis, in the other three glasses this was not the case.

In our case we made similar tests as follows:-

1. Defibrinated blood for two hours in a small glass at normal indoor temperature : no hæmolysis.

2. Defibrinated blood for two hours at normal indoor temperature under a bell filled with $\mathrm{CO}_{2}$ : strong hæmolysis. 3. Defibrinated blood for two hous at $37^{\circ} \mathrm{C}$ : : no hæmolysis.

4. Defibrinated blood for two hours at $37^{\circ} \mathrm{C}$. under a bell-jar filled with $\mathrm{CO}$ : no hæmolysis or only a trace.

5. The same four tests with defibrinated blood of a normal person : no hæmolysis.

6. Patient's serum + his washed erythrocytes (proportion 1 c.cm. to 1 drop) two hours at normal indoor temperature: no hæmolysis.

7. Patient's serum + ervthrocytes two hours at normal indoor temperature in an atmosphere of $\mathrm{CO}_{2}$ : strong hæmolysis.

8. Patient's serum + erythrocytes two hours at $37^{\circ} \mathrm{C}$. no hæmolysis or sometimes a trace.

9. Patient's serum + erythrocytes two hours at $37^{\circ} c^{\circ}$. in atmosphere of $\mathrm{CO}_{2}$ : no hæmolysis or slight trace.

\section{Explanation of Diverse Results Obtained.}

By these experiments it is clearly proved that (as has been first demonstrated by Hymans van den Bergh and confirmed by Krokiewicz) carbonic acid gas, both in defibrinated blood and in a mixture of serum and washed red blood corpuscles of the patient, is capable of causing distinct hæmolysis at ordinary laboratoly temperature. The results of our experiments, as her"e set down, were only obtained after the test had besn carried out with the utmost care. Experiments 1 and 9 especially showed at first other results, and a distinct, albeit not pronounced, hæmolysis was to be traced, this being contrary to the experiences of Hymans van den Bergh and Hymans, who at $37^{\circ}:{ }^{\prime}$. observed no effects of the carbonic acid gas.

We soon got to the bottom of the cause of thi apparent diversity. In our first experiments we filled the watch-glasses with defibrinated blood (or with serum and erythrocytes) and glass bells with carbo:lic 
acid gas, which had been kept at normal indoor temperature; we used glass utensils which also had not been warmed beforehand. We thought, therefore, that the unexpected results of experiments 4 and 9 might perhaps be due to the fact that for a short period blood and $\mathrm{CO}_{2}$ had been in contact before they had reached the temperature of the incubator. We therefore repeated these experiments, after previously placing the blood, the serum, the washed bloodcorpuscles, and all the instruments to be used for some time in the incubator. The various stages of the experiment were then carried out as quickly as possible in the immediate neighbourhood of the incubator. A certain loss of heat was, of course, even then unavoidable, but the result was very different from that obtained in the previous experiments, when these precautions had not been taken; we now observed no hæmolysis, or only extremely slight signs of it. (In this connexion we should mention the fact that Hymans van den Bergh and Hymans once noted a slight hæmolysis in the incubator experiment on an occasion when, by some neglect, the temperature had been allowed to fall to $32^{\circ} \mathrm{C}$. instead of being kept at $37^{\circ}$ C.)

\section{Importance of Carbonic Acid Gas.}

We are of opinion that in these experiments we have as close an imitation as is possible of what nature shows us in the case of sufferers from paroxysmal hæmoglobinuria. If the patient has an attack, after being out in the cold, the blood in hands and feet can only be slightly chilled before reaching the more protected parts of the body. Such patients are often sufferers from vasomotor disturbances, while the somewhat chilled blood is liable to exposure to a certain amount of carbonic acid gas collected in the system. "The following observations are remarkable in this connexion. As we have already stated above, Chrostek proved that in some cases the simple ligature of an extremity, thus causing an accumulation of carbonic acid gas in that part, was enough to provoke an attack. Burchhardt, however, who also made this statement, noted that the attack did not take place if the ligatured finger was at the same time kept at a temperature of $37^{\circ} \mathrm{C}$. The slight chill to which, in the test case of Chvostek, the ligatured members were undoubtedly exposed and which Burchhardt avoided, was thus sufficient to submit the blood in the ligatured member to the influence of the carbonic acid gas. Our own experiments also proved that the slight chill to which the blood was exposed was capable of exciting hæmolysis in an atmosphere of carbonic acid gas. From these experiments we therefore come to the obvious conclusion that carbonic acid gas plays a very important part, and that a mere chilling of the blood is sufficient to make evident its effect. At this juncture we cast about for some rational explanation of the action of the carbonic acid gas and judged the first step in this direction to be an examination of the patient's blood, with a view to ascertaining whether the corpuscles or the serum revealed any peculiarity as compared to the blood of a normal person. To this end we made the following experiments:-

1. Patient's serum + patient's erythrocytes for two hours at normal indoor temperature in $\mathrm{CO}_{2}$ atmosphere: strong hæmolysis.

2. Patient's serum + normal erythrocytes for two hours at normal indoor temperature in $\mathrm{CO}_{2}$ atmosphere: strong hæmolysis.

3. Normal serum + patient's erythrocytes two hours at normal indoor temperature in $\mathrm{CO}_{2}$ atmosphere: no hæmolysis.

1. Normal serum + normal erythrocytes two hours at normal indoor temperature in $\mathrm{CO}_{2}$ atmosphere: no hæmotysis.

5. Patient's washed erythrocytes two hours at normal indoor temperature in $\mathrm{CO}_{2}$ atmosphere: no hæmolysis.

From which we conclude, as Hymans van den Bergh did, that it was the patient's serum, not his blood corpuscles, which contained some abnormal property.

We were now faced by the following important question: Is it possible that the carbonic acid gas causes such changes in the serum that the latter, after the former has been removed, proves to have acquired hromolytic properties from it when brought into contact with erythrocytes ? That chilling alone, eren to $0^{\circ} \mathrm{C}$., cannot do this has been proved by Choroschilow, who modified Donath and Landsteiner's experiment by placing only the serum in ice and adding the erythrocytes to it later. The result was negative. We carried out our tests as follows:-

1. Patient's serum was kept two hours at normal indoor temperature.

2. Patient's serum was kept two hours at normal indoor temperature in $\mathrm{CO}_{2}$ atmosphcre.

3. Patient's serum was kept two hours at $37^{\circ} \mathrm{C}$.

4. Patient's serum was kept two hours at $37^{\circ} \mathrm{C}$. in $\mathrm{CO}_{2}$ atmosphere.

At the end of the two hours sera 2 and 1 were taken out of the $\mathrm{CO}_{2}$ atmosphere. They were poured from the original watch-glasses into test-tubes and these were well shaken. One might then presume that they were no longer under the influence of the CO. We should mention that all the utensils used for tests 3 and 1 had been warmed beforehand and that the sera in tests 2 and 1 were poured from the watch-glasses into warmed test-tubes.

After this the four above-mentioned sera were each divided into two parts: to the one portion of each serum washed erythrocytes of the patient were added; to the other washed erythrocytes of a normal person, all in a proportion of 1 drop ervthrocytes to $1 \mathrm{c} . \mathrm{cm}$. serum. The eight portions were then ylaced for half an hour in the incubator and afterwards centrifuged. It then appeared that both the erythrocytes of the patient and those of the normal person were very strongly hæmolysed by the serum which had previously been exposed to $\mathrm{CO}_{2}$ at normal indoor temperature. In none of the other test-tubes was a trace of hæmolysis to be seen.

From this it is clear that in the case of our patient carbonic acid gas at normal indoor temperature brought about such changes in the serum that, after being placed in the incubator, this proved to possess a hremolytic action on the erythrocytes which had been brought into contact with it after the carbonic acid gas had been removed. It is, of course, difficult to define exactly what changes the carbonic acid gas actually brings about. It is well known that hamolysis of red blood corpuscles in a hæmolytic serum is caused by two substances, an amboceptor and a complement. This latter is destroyed when a serum is heated for half an hour to $56^{\circ} \mathrm{C}$. We repeated all the aforementioned experiments with the patient's serum rendered thus inactive without finding any trace of hremolysis, from which one would be tempted to conclude that the heating had simply destroyed the complement. The matter is, however, not so simple. as is witnessed by the fact that Hymans van den Beroh. who produced these same results with serum thus rendered inactive, could not re-induce activity by adding normal serum, as is possible with other hremolytic sera. One can only say for the present that heating not only destroys the complement, but also withdraws from the serum the power to create or activate the hxmolytic amboceptor of paroxysmal hæmoglobinuria. According to the foregoing evidence it must be the carbonic acid gas, which, at a temperature lower than that of the body, caused this amboceptor to become active in the patient's serum.

\section{Widal's Experiment.}

Widal, Abrami, and Brissaud published in the Semaine IIédicale, in 1913, a very interesting article on paroxysmal hrmoglobinuria. They attempted to prove the existence of three different substances in the serum by the following experiment. They placed serum and erythrocytes taken from their patients suffering from paroxysmal hæmoglobinuria for a long period $(4-16$ hours $)$ in ice; it then appeared that the erythrocytes, afterwards centrifuged, washed, and placed in physiological salt solution, showed no hæmolysis at $37^{\circ} \mathrm{C}$. . notwithstanding the fact that the serum on being tested was found no longer to contain any complement. The erythrocrtes, which after such long period had absorbed both of the necessary materials for hæmolysis, ought to have hæmolysed at $37^{\circ} \mathrm{C}$. ; from the fact that this was not the case, Widal and his colleagues deduced that the erythro- 
crtes had drarn out of the serum some third substance, an anti-hæmolysin. They believed the serum to contain amboceptor, complement, and anti-hæmolysin, which three balance each other in a normal body and are dissociated at a lower temperature whereby the tro first-named substances are no longer under. restraint, thus precipitating hemolrsis. If this theory is correct, then it appears from our experiments that chill alone (at least in vitro) cannot produce hæmolysis, but that the influence of the carbonic acid gas at a temperature lower than that of the body causes the dissociation spoken of br Widal.

HLaving thus finished in the laboratory, we had to consider the correct method of treatment. Syphilis having been admitted and the Wassermann reaction being rery stronglr positive. the first thing to do was to combat the syphilis. Widal, Lbrami. and Brissaud, in the article above quoted, proposed as a therapeutic mehsure a repeated injection (sereral times in -uecession) of a small quantity of the patient's own serum. Their idea was based on the argument that they regarded the serum of the patient as a heterogenic albumin and thus by repeated small injections, an anti-anaphylactic condition of the patient could be effected. The writers report farourable results from this treatment.

As will readily be understood. we much desired to make a trial of this new method, but felt ourselves morally obliged to submit the man first to antisyphilitic treatment. We therefore treated him in the usual manner with potassium iodide. mercury, and salvarsan. We were curious as to whether these agent: had not perhaps altered the abnormal properties of the patient's blood; we therefore repeated all the above-mentioned experiments with absolutely the same results as before. The anti-syphilitic treatment had thus caused no changes. It was a great disappointment that we were not able to apply the method of Widal. Abrami, and Brissaud; the patient could not be persuaded to stay any longer in hospital. He left in April, 1921, and we have heard nothing more of him.

Bibliography.-Burchhardt: Jahrb. f. Kinderh., 1903. Choroschilow : Z. f. Klin. Med., Bd. lxir.. Donath and Landsteiner: Munch. med. Woch., 1904, No. 36. Hymans van den Bergh and Hymans, C.: Berlin. Klin. Woch., 1909 , Nos. 27 and 35. Krokiewicz: Wien. Klin. Woch., 1911, No. 14. Posin : Kongr. f. Inn. Mediz., xxvii., S. 454 .
TARIATIONS OF BLOOD PRESSCRE

TNDER INTRATENOES INJECTIONS OF PHENOLIC COMPOUNDS (ARSENOBENZOLS. $606,914, \mathrm{dc}$.$) .$

BY DR. M, POMARET.

Is my recent physiological study of the phenomena of shock following intrarenous injections of arsenobenzols. which appeared in the French Supplement to 'THe LAscet of Dec. 2nd. I described the variations of blood pressure registered in my experiments on dogs. The chart which follows shors these variations in detail.

In the experiments the rariations were registered in the carotids of dogs, anæsthetised with chloralose. The injections of phenolic compounds were made into the saphenous vein. The fall in blood pressure. constituting. as I said previously, the main phrsiological srmptom of the existence of shock. the tracings which follow show graphically the cardiorascular action produced br the phenolic compounds. injected in such conditions that they determine at first flocculation and secondaril a makked fall of blood pressure and sometimes cardiac collapse.

FIr. 1.-Rapid fall of hlood pressure and fatal cardiac collapse after intravenous injec tion of 1.30 g. norarsenobenzol 4911;, disoulved in a solution of 2 per cent. tartaric ateid.

Fre. 2.-. Shows the same with 1.20 g. of novarsenobenzol (91t) (lissolved in $5 \mathrm{cccm}$. of a $\%$ per cent. solution of tartarie acid. Dog. weighing $20.600 \mathrm{lgr}$. anæsthetised with rhloralose.

FIs. 3.-Dog weighing $17 \mathrm{kgr}$. anæs thetised with chloralose. First injeeted with an alkaline -ulution of $6060(0.50 \mathrm{~g}$. arsenobenzol in 50 e.cm., containiug 1.2 c.cm. of NaOH-N). The lall of bluod pressme was small and tran-itor $r$, but the intravenou injection of only $11.15 \mathrm{~g}$. of 606 . dissolved in $7 \mathrm{c} . \mathrm{cm}$. of water (acid and precipitating solution) was followed hy an immediate fall of blood iressure, which was not compensated for by the injection of a: a alkaline solution $\left(\mathrm{CO}_{3} \mathrm{Na}_{2}\right)$. Death in cardiac collapse.

Fig. 1.- Shock and fall of blood pressure after in travenous injection of $20 \mathrm{c.cm}$. of solution of 1 percent. pieric acid (trinitrophenol).

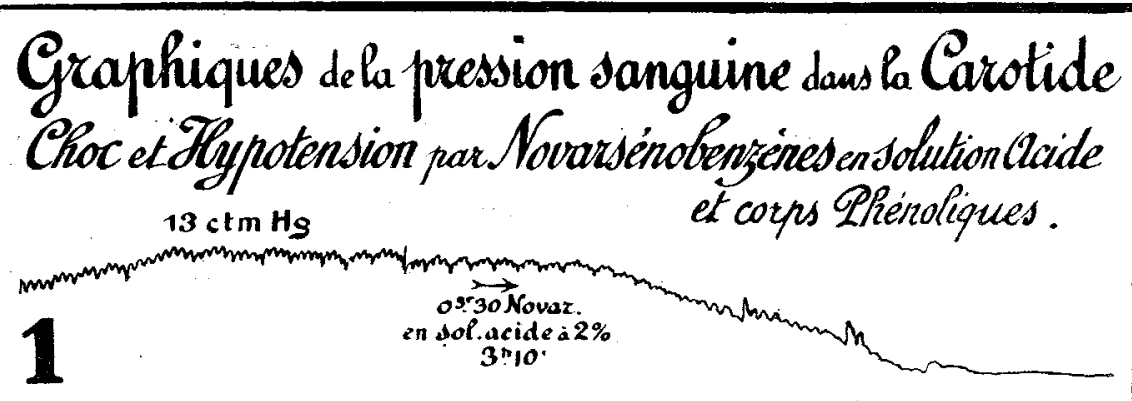

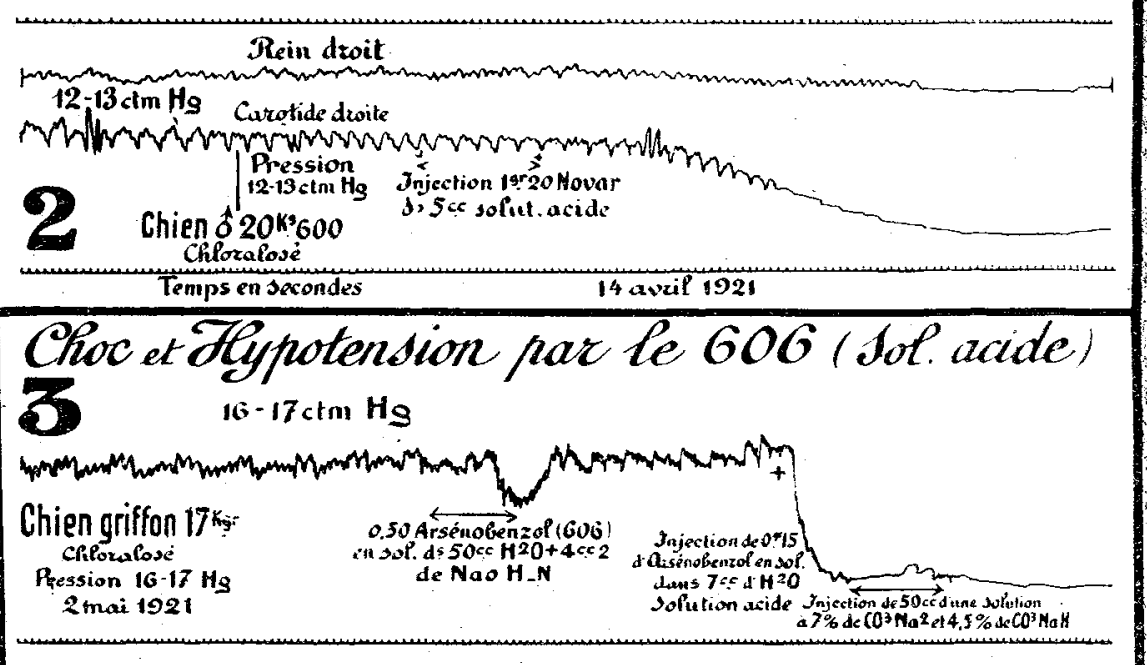

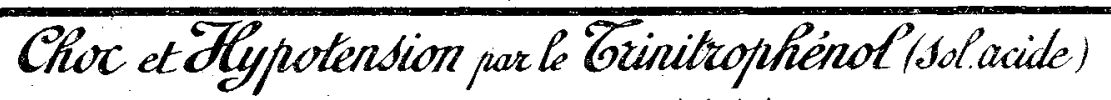
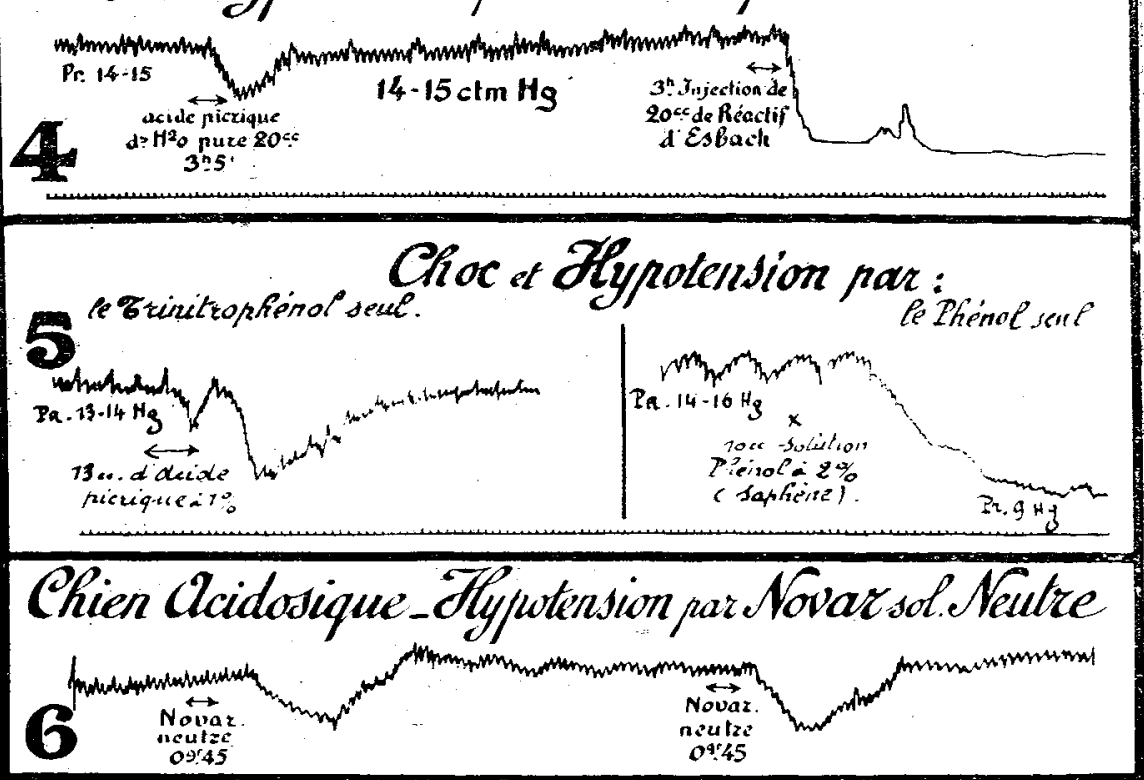